\title{
Blood Groups and Genetic Serum Types in Diabetes Mellitus
}

\author{
K. Berg*, S. Aarseth, J. Lundevall and T. Reinskou \\ The Institute of Forensic Medicine, University of Oslo, Oslo, and The Department \\ of Internal Medicine, Diakonhjemmets sykehus, Oslo
}

Received August 29, 1966

\begin{abstract}
Summary. An investigation of possible association between diabetes mellitus and blood groups and genetic serum types has been performed. 190 patients with diabetes mellitus were tested for several genetic erythrocyte and serum protein markers, and compared with healthy controls. An association between diabetes mellitus and the ABO system, as reported in earlier literature, was not found. Although the results in the Rh, $\mathrm{Hp}$ and $\mathrm{Gm}$ systems indicated an association with diabetes mellitus, these findings have been interpreted with caution. No association was found for the MN, Kell, Ge, Ld, Lp or Ag systems.
\end{abstract}

Groupes sanguins et types génétiques du sérum dans le diabète sucré.

Résumé. La question d'une association possible entre le diabète sucré, les groupes sanguins et les types génétiques du sérum a été étudiée. 190 patients atteints de diabète ont été examinés pour des caractéristiques génétiques des érythrocytes et des protéines du sérum avec comparaison des résultats avec des personnes de contrôle. Une association entre le diabète et le système $\triangle B O$, rapportée dans la littérature antérieure, n'a pas été trouvée. Les résultats pour les systèmes $\mathrm{Rh}, \mathrm{Hp}$ et Gm qui pour- raient indiquer une association avec le diabète ont été interprétés avec précaution. Aucune association ne se trouvait pour les systèmes MN, Kell, Gc, Ld, Lp ou Ag.

Blutgruppen und genetische Serumtypen bei Diabetes
mellitus.
Zusammenfassung. Es wird eine Untersuchungsreihe über den möglichen Zusammenhang zwischen Diabetes mellitus, Blutgruppen und genetischen Serumtypen vorgelegt. 190 Patienten mit Diabetes mellitus wurden im Hinblick auf verschiedene genetische Erythrocyten- und Serumeiweißkennzeichen untersucht und mit einer normalen Kontrollgruppe verglichen. Ein Zusammenhang zwischen Diabetes mellitus und dem ABO-System, wie dies in der früheren Literatur berichtet wurde, ließ sich nicht feststellen. Obgleich die Ergebnisse in den. Rh-, Hpund $\mathrm{Gm}$-Systemen eine Beziehung zum Diabetes mellitus aufzeigten, wurden diese Befunde mit Vorsicht interpretiert. Keine Beziehung wurde für die MN-, Kell-, Gc-, Ld-, Lp- oder Ag-Systeme gefunden.

Key-words: Diabetes mellitus, blood groups, serum types, genetics, association, $\mathrm{Rh}$ system.
An association between a blood group and disease, was first demonstrated by AIRD, BenTaLl and RoBERTS (1953). In an investigation of diabetes mellitus (McConnell, Pyke and Roberts, 1956), an association with blood group A was found. Later studies have failed to confirm this finding (ANDERSEN and LATRITZEN, 1960; MaCAFeE, 1964).

The information on the distribution of genetically determined serum protein types in diabetes mellitus is meagre. The haptoglobin types of 98 patients (SIMPson, GUNson and SMithies, 1962), showed no significant deviation from the control material. The finding of an increased frequency of the phenotype $\mathrm{Ag}(\mathrm{a}+)$ among patients with diabetes mellitus (BLUMrBerg, 1964), suggested a relation between a genetic $\beta$-lipoprotein type and diabetes mellitus. Thus it appeared particularly interesting to confirm this finding, and to investigate whether there was any association between this disease and the 2 new genetic systems of $\beta$-lipoportein; the Lp and Ld systems (BERG, 1963; BERG, 1965).

In view of the conflicting blood group findings, and the limited data on serum types, an investigation of blood groups and serum types in diabetes mellitus

* Supported by the fund "Aktieselskabet Freia Chocolade Fabriks Medicinske Fond", Oslo. has been performed. The data are reported in detail, so that information that may emerge from future studies can be added.

\section{Materials}

Diabetes mellitus patients. All the patients with diabetes mellitus available at the Hospital of Det Norske Diakonhjem, Oslo, in the period from February 14 to July 3, 1964, were included in the investigation. The majority of the diabetes mellitus patients were out-patients attending regularly at the Department of Internal Medicine; the remainder were hospitalized patients in the same department. In all, samples from 190 patients from the Oslo area were obtained; 86 were males and 104 were females. The mean age of the males was 50.5 years (range: $14-86$ years) and of the females 57.2 years (range: $14-86$ years). Not all patients were tested for all markers under study, hence, for a number of comparisons, somewhat less than 190 patients are included. No clinical subdivision of the patients with diabetes mellitus was made because of the small number.

None of the patients had received blood transfusions in the 3 months prior to obtaining the blood sample.

Controls. For each system, the patients were com- 
pared with the largest published material of unrelated, normal individuals from the same area of Oslo. The following were used as controls: for the $\mathrm{ABO}$ and MNS systems, 3089 persons tested by HaRTMANN and LundeVaLL (1944); for the Rh system, 1000 persons tested by Hartiana, Brendemoen and BrendeMOEN (1951); for the Kell system, 1000 persons tested by HeIstö (1953); for the Ge system, 978 persons tested by ReINskou (1965); for the Hp system, 1000 persons tested by Fleischer and Lundevalu (1958); for the Gm system, 680 persons tested by HARBOE and LUNDEVALL (1961); for the Ld system, 162 persons tested by BeRg (1965); for the Lp system, 314 persons tested by BERG (1963) and for the Ag system, 187 persons tested by BeRG (1964). Whenever the statistical tests performed with these controls indicated an association between diabetes mellitus and a genetic marker, the association was retested with a different control group consisting of unrelated adults involved in paternity cases, tested in the same laboratory, with the same reagents, by the same person, on the same day as the patient group. When this smaller control material was compared with the larger control material, no significant indication of heterogeneity in any genetic system was found. of each blood sample was separated, and the tests were performed. Both the serum and erythrocytes from each sample were given code numbers and included in the routine tests of samples from persons involved in paternity cases. Thus, the persons performing and reading the tests did not know which samples were from patients and which from individuals involved in cases of disputed paternity. The classification within the erythrocyte systems, as well as within the serum systems Gc, Hp and Gm, was made using well known, standard techniques. The Rh type determinations were performed with the following 4 antisera: anti-C, anti-D, anti-E, and anti-c. Some of the rarer genotypes were therefore not distinguished from the more frequent ones (for details, see Table 32 in RACE and SANGER (1962)), but the frequencies of the complexes $R^{\prime}, R_{0}, R^{\prime \prime}$, and $R_{\mathrm{z}}$ are low in the normal Norwegian population. Tests for the genetic, antigenic variants of the $\beta$-lipoproteins were performed as described earlier (BERG, 1965). The anti-Ag(a) serum was kindly given to us by Dr. B.S. Blumberk, National Institutes of Health, Bethesda. The anti-Lp(a) and anti-Ld(a) sera have been described earlier (BERG, 1963; BERG, 1965).

Statistical analysis. The patients and controls were arranged in $2 \times \mathrm{n}$ tables according to their genetic

Table 1. The ABO system. Distribution of diabetes mellitus patients and controls

\begin{tabular}{|c|c|c|c|c|c|c|c|}
\hline & \multicolumn{6}{|c|}{ Blood group } & \multirow{2}{*}{ Total } \\
\hline & $A_{1}$ & $A_{2}$ & B & $A_{1} B$ & $A_{2} B$ & 0 & \\
\hline $\begin{array}{l}\text { Diabetes mellitus } \\
\text { patients }\end{array}$ & $\begin{array}{l}\text { Obs. } 74 \\
\text { (Exp. 72.8) }\end{array}$ & $\begin{array}{l}\text { Obs. } 17 \\
\text { (Exp. 14.1) }\end{array}$ & $\begin{array}{l}\text { Obs. } 13 \\
(\operatorname{Exp} .14 .7)\end{array}$ & $\begin{array}{l}\text { Obs. } 3 \\
(\text { Exp. 5.0) }\end{array}$ & $\begin{array}{l}\text { Obs. 0 } \\
(\text { Exp. 1.1) }\end{array}$ & $\begin{array}{l}\text { Obs. } 69 \\
\text { (Exp. 68.3) }\end{array}$ & 176 \\
\hline Controls & $\begin{array}{l}\text { Obs. } 1276 \\
\text { (Exp. 1277.2) }\end{array}$ & $\begin{array}{l}\text { Obs. } 245 \\
\text { (Exp. 247.9) }\end{array}$ & $\begin{array}{l}\text { Obs. } 259 \\
\text { (Exp. 257.3) }\end{array}$ & $\begin{array}{l}\text { Obs. } 90 \\
(\operatorname{Exp} .88 .0)\end{array}$ & $\begin{array}{l}\text { Obs. } 20 \\
\text { (Exp. 18.9) }\end{array}$ & $\begin{array}{l}\text { Obs. } 1199 \\
(\text { Exp. 1199.7) }\end{array}$ & 3089 \\
\hline Total & 1350 & 262 & 272 & 93 & 20 & 1268 & 3265 \\
\hline
\end{tabular}

Table 2. The MN system. Distribution of diabetes mellitus patients and controls

\begin{tabular}{|c|c|c|c|c|}
\hline & \multicolumn{3}{|c|}{ Blood group } & \multirow{2}{*}{ Total } \\
\hline & $\mathrm{M}$ & $\mathrm{MN}$ & $\mathrm{N}$ & \\
\hline $\begin{array}{l}\text { Diabetes mellitus } \\
\text { patients }\end{array}$ & $\begin{array}{l}\text { Obs. } 49 \\
(\operatorname{Exp} .50 .5)\end{array}$ & $\begin{array}{l}\text { Obs. } 90 \\
\text { (Exp. 91.1) }\end{array}$ & $\begin{array}{l}\text { Obs. } 41 \\
\text { (Exp. 38.4) }\end{array}$ & 180 \\
\hline Controls & $\begin{array}{l}\text { Obs. } 868 \\
\text { (Exp. 866.5) }\end{array}$ & $\begin{array}{l}\text { Obs. } 1565 \\
\text { (Exp. 1563.9) }\end{array}$ & $\begin{array}{l}\text { Obs. } 656 \\
\text { (Exp. 658.6) }\end{array}$ & 3089 \\
\hline Total & 917 & 1655 & 697 & 3269 \\
\hline
\end{tabular}

\section{Methods}

Samples of venous blood were collected from the diabetic in-patients and out-patients on the same day of each week. The samples were allowed to clot for 1 hour at $37^{\circ} \mathrm{C}$, and were kept overnight at $4^{\circ} \mathrm{C}$. The next day, they were transported to the Institute of Forensic Medicine, University of Oslo, where the serum type, and the $\chi^{2}$ test applied to the tables. Whenever an expected number was less than five, YATES' correction for continuity was applied.

\section{Results}

No suggestion of association between diabetes mellitus and the ABO (Table 1) or MN (Table 2) blood 
groups was found. Comparisons in the Rh system gave a $P$ value of less than 0.01 (Table 3).

Particularly the cells dealing with the types $R_{1} R_{2}$, $R_{2} r$, and $R_{2} R_{2}$, and $R_{1} R_{1}$, contributed significantly to the high $\chi^{2}$-value, and it can be seen from Table 3 , that there was an excess of persons possessing the $R_{2}$
An increased number of individuals of haptoglobin type 1-1 and a decreased number of persons of type 2-2 were found among the diabetes mellitus patients (Table 6).

The difference in the distribution of the haptoglobin types between diabetes patients and healthy per-

Table 3. The Rh system. Distribution of diabetes mellitus patients and controls

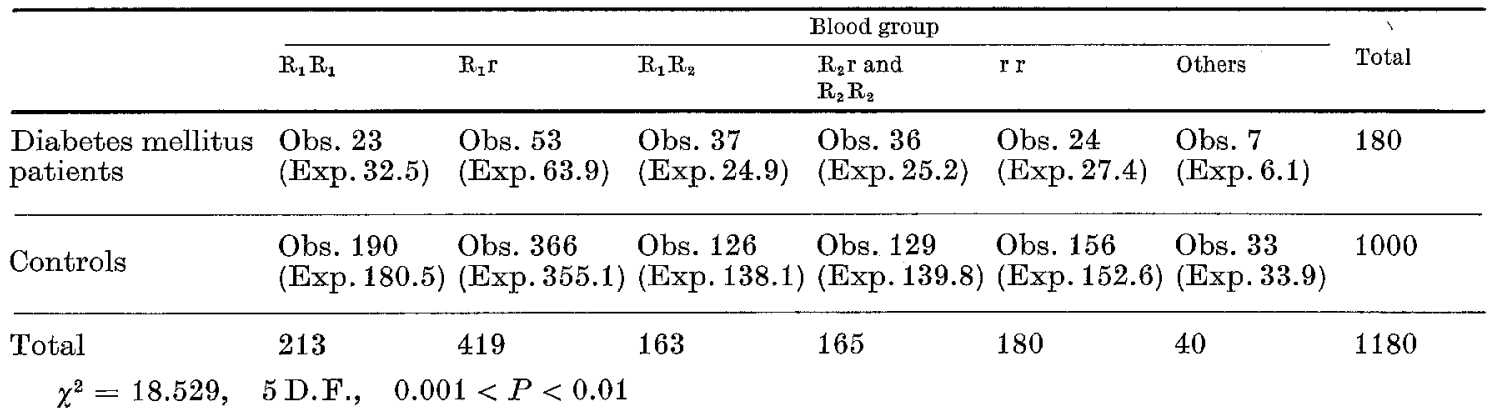

Table 4. The Kell system. Distribution of diabetes mellitus patients and controls

\begin{tabular}{llll}
\hline & \multicolumn{2}{l}{ Blood group } & Total \\
\cline { 2 - 3 } $\begin{array}{l}\text { Diabetes } \\
\text { mellitus } \\
\text { patients }\end{array}$ & $\begin{array}{l}\text { Obs. } 8 \\
\text { (Exp. 14.4) }\end{array}$ & $\begin{array}{l}\text { Obs. 164 } \\
\text { (Exp. 157.6) }\end{array}$ & 172 \\
\hline Controls & $\begin{array}{l}\text { Obs. 90 } \\
\text { (Exp. 83.6) }\end{array}$ & $\begin{array}{l}\text { Obs. 910 } \\
\text { (Exp. 916.4) }\end{array}$ & 1000 \\
\hline Total & 98 & 1074 & 1172 \\
$\chi^{2}=3.639$, & 1 D.F., $0.05<P<0.10$ &
\end{tabular}

Table 5. The Ge system. Distribution of diabetes mellitus patients and controls

\begin{tabular}{|c|c|c|c|c|}
\hline & \multicolumn{3}{|l|}{ Ge type } & \multirow{2}{*}{ Total } \\
\hline & $1-1$ & $2-1$ & $2-2$ & \\
\hline $\begin{array}{l}\text { Diabetes mellitus } \\
\text { patients }\end{array}$ & $\begin{array}{l}\text { Obs. } 102 \\
\text { (Exp. 97.9) }\end{array}$ & $\begin{array}{l}\text { Obs. } 74 \\
\text { (Exp. 79.4) }\end{array}$ & $\begin{array}{l}\text { Obs. } 14 \\
\text { (Exp. 12.7) }\end{array}$ & 190 \\
\hline Controls & $\begin{array}{l}\text { Obs. } 500 \\
(\text { Exp. } 504.1)\end{array}$ & $\begin{array}{l}\text { Obs. } 414 \\
(\operatorname{Exp} .408 .6)\end{array}$ & $\begin{array}{l}\text { Obs. } 64 \\
\text { (Exp. 65.3) }\end{array}$ & 978 \\
\hline Total & 602 & 488 & 78 & 1168 \\
\hline & D.F., & $<0.70$ & & \\
\hline
\end{tabular}

complex among the diabetes mellitus patients. The diabetes mellitus patients were also compared with 167 unrelated, adult persons involved in paternity cases. The comparisons again showed a tendency for an increased number of $R_{1} R_{2}$ and a decreased number of $R_{1} R_{1}$ individuals among the diabetes mellitus patients, but the difference was not statistically significant $(0.10<P<0.20)$ with this small control material. No indication of heterogeneity was found between the two control groups $(0.10<P<0.20)$.

No association between diabetes mellitus and the Kell blood group (Table 4) or the Gc serum types (Table 5) was found. sons was significant $(0.01<P<0.02)$. The same trend emerged when 166 unrelated, healthy adults involved in paternity cases were used as controls, but this smaller control material gave a much lower $\chi^{2}$, and the difference was not significant $(0.10<P<0.20)$.

An apparent association emerged also in the comparisons for the Gm system (Table 7). The highest contribution to the $\chi^{2}$ value resulted from an excess of $a+b-x+$ people, and a relative lack of $a+b-x-$ persons in the patient group. The same tendency was observed when the patients were compared with 167 persons of the smaller control group, but the difference was not significant $(0.05<P<0.10)$.

No indication of association between diabetes mellitus and the $\beta$ lipoprotein systems Ld (Table 8), Lp (Table 9) or Ag (Table 10) was found.

\section{Discussion}

No indication of association between the ABO groups and diabetes mellitus was found in the present study. In view of the conflicting earlier reports, it seems reasonable to conclude that the total body of data presently available does not support the suggestion of McConnell, Pyke and Roberts (1956) of an association between diabetes mellitus and the ABO system.

The lack of association in our material between diabetes mellitus and the MN and Kell systems is in agreement with findings by earlier investigators (McConnell, Pyke and Roberts, 1956; Simpson, GunSON and SMITHIEs, 1962; MACAFEe, 1964).

The $\mathrm{Rh}$ system was included in earlier investigations of diabetes mellitus and blood groups (McCoNNeli, Pyke and Roberts, 1956; ANderisen and LAURITzen, 1960; Simpson, Gunson and Smitmies, 1962), but no significant indication of an association was 
found. In these investigations the Rh types were scored simply as "Rh positive" and "Rh negative". In the study of BUCKWALTER and TwEED (1962) the diabetic and a decreased number of $R_{1} R_{1}$ individuals among the diabetes mellitus patients, although the difference was not statistically significant. The possible association

Table 6. The Hp system. Distribution of diabetes mellitus patients and controls

\begin{tabular}{lllll}
\hline & Hp type & & & Total \\
\cline { 2 - 4 } $\begin{array}{l}\text { Diabetes mellitus } \\
\text { patients }\end{array}$ & $\begin{array}{l}\text { Obs. 39 } \\
(\text { Exp. 27.3) }\end{array}$ & $\begin{array}{l}\text { Obs. 90 } \\
(\text { Exp. 88.1) }\end{array}$ & $\begin{array}{l}\text { Obs. 61 } \\
(\text { Exp. 74.6) }\end{array}$ & 190 \\
\hline Controls & $\begin{array}{l}\text { Obs. 132 } \\
(\text { Exp. 143.7) }\end{array}$ & $\begin{array}{l}\text { Obs. 462 } \\
(\text { Exp. 463.9) }\end{array}$ & $\begin{array}{l}\text { Obs. 406 } \\
(\text { Exp. 392.4) }\end{array}$ & 1000 \\
\hline Total & 171 & 552 & 467 & 1190 \\
$\chi^{2}=8.966$, & 2 D.F., 0.01 $<P<0.02$ & &
\end{tabular}

Table 7. The Gm system. Distribution of diabetes mellitus patients and controls

\begin{tabular}{|c|c|c|c|c|c|c|}
\hline & \multicolumn{5}{|l|}{ Gm type } & \multirow{2}{*}{ Total } \\
\hline & $a^{+} b^{-} x^{-}$ & $a^{+} b^{-} x^{+}$ & $a^{+} b^{+} x^{+}$ & $a^{-} b^{+} x^{-}$ & $a^{+} b^{+} x^{-}$ & \\
\hline $\begin{array}{l}\text { Diabetes mellitus } \\
\text { patients }\end{array}$ & $\begin{array}{l}\text { Obs. } 5 \\
\text { (Exp. 10.7) }\end{array}$ & $\begin{array}{l}\text { Obs. } 24 \\
\text { (Exp. 15.6) }\end{array}$ & $\begin{array}{l}\text { Obs. } 30 \\
\text { (Exp. 37.2) }\end{array}$ & $\begin{array}{l}\text { Obs. } 71 \\
(\text { Exp. 71.1) }\end{array}$ & $\begin{array}{l}\text { Obs. } 59 \\
(\operatorname{Exp} .54 .4)\end{array}$ & 189 \\
\hline Controls & $\begin{array}{l}\text { Obs. } 44 \\
(\operatorname{Exp} .38 .3)\end{array}$ & $\begin{array}{l}\text { Obs. } 48 \\
(\operatorname{Exp} .56 .4)\end{array}$ & $\begin{array}{l}\text { Obs. } 141 \\
(\operatorname{Exp} .133 .8)\end{array}$ & $\begin{array}{l}\text { Obs. } 256 \\
(\text { Exp. 255.9) }\end{array}$ & $\begin{array}{l}\text { Obs. } 191 \\
\text { (Exp. 195.6) }\end{array}$ & 680 \\
\hline Total & 49 & 72 & 171 & 327 & 250 & 869 \\
\hline$\chi^{2}=11.936$ & 4 D.F., & $<P<0.02$. & & & & \\
\hline
\end{tabular}

Table 8. The Ld system. Distribution of diabetes mellitus patients and controls

\begin{tabular}{|c|c|c|c|}
\hline & \multicolumn{2}{|l|}{ Ld type } & \multirow{2}{*}{ Total } \\
\hline & $\overline{\mathbf{L d}\left(\mathrm{a}^{+}\right)}$ & $\operatorname{Ld}\left(\mathrm{a}^{-}\right)$ & \\
\hline $\begin{array}{l}\text { Diabetes } \\
\text { mellitus } \\
\text { patients }\end{array}$ & $\begin{array}{l}\text { Obs. } 80 \\
\text { (Exp. 80.4) }\end{array}$ & $\begin{array}{l}\text { Obs. } 110 \\
\text { (Exp. 109.6) }\end{array}$ & 190 \\
\hline Controls & $\begin{array}{l}\text { Obs. } 69 \\
(\text { Exp. 68.6) }\end{array}$ & $\begin{array}{l}\text { Obs. } 93 \\
\text { (Exp. 93.4) }\end{array}$ & 162 \\
\hline Total & 149 & 203 & 352 \\
\hline
\end{tabular}

Table 9. The Lp system. Distribution of diabetes mellitus patients and controls

\begin{tabular}{|c|c|c|c|}
\hline & \multicolumn{2}{|l|}{ Lp type } & \multirow{2}{*}{ Total } \\
\hline & $\operatorname{Lp}\left(a^{+}\right)$ & $\mathrm{Lp}\left(\mathrm{a}^{-}\right)$ & \\
\hline $\begin{array}{l}\text { Diabetes } \\
\text { mellitus } \\
\text { patients }\end{array}$ & $\begin{array}{l}\text { Obs. } 55 \\
\text { (Exp. 61.1) }\end{array}$ & $\begin{array}{l}\text { Obs. } 135 \\
\text { (Exp. 128.9) }\end{array}$ & 190 \\
\hline Controls & $\begin{array}{l}\text { Obs. } 107 \\
\text { (Exp. 100.9) }\end{array}$ & $\begin{array}{l}\text { Obs. } 207 \\
(\text { Exp. 213.1) }\end{array}$ & 314 \\
\hline Total & 162 & 342 & 504 \\
\hline
\end{tabular}

patients were genotyped, and they concluded that there was no association between the $\mathrm{Rh}$ system and diabetes mellitus. However, their results showed that there was a tendency towards an increased number of $R_{1} R_{2}$
Table 10. The Ag system. Distribution of diabetes mellitus patients and controls

\begin{tabular}{llll}
\hline & \multicolumn{1}{c}{$\begin{array}{l}\mathrm{Ag} \text { type } \\
\mathrm{Ag}\left(\mathrm{a}^{+}\right)\end{array}$} & Total \\
\hline $\begin{array}{l}\text { Diabetes } \\
\text { mellitus } \\
\text { patients }\end{array}$ & $\begin{array}{l}\text { Obs. 76 } \\
(\text { Exp. 72.2) }\end{array}$ & $\begin{array}{l}\text { Obs. 102 } \\
\text { (Exp. 105.8) }\end{array}$ & 178 \\
\hline Controls & $\begin{array}{l}\text { Obs. 72 } \\
(\text { Exp. 75.8) }\end{array}$ & $\begin{array}{l}\text { Obs. 115 } \\
(\text { Exp. 111.2) }\end{array}$ & 187 \\
\hline Total & 148 & 217 & 365 \\
\multicolumn{1}{c}{$\chi^{2}=0.657}$, & 1 D.F., $0.30<P<0.50$. &
\end{tabular}

between diabetes mellitus and the $R_{2}$ complex suggested in our data, obviously needs further studies for a final evaluation.

Although our data showed an excess of people of haptoglobin type 1-1 among the patients, it seems likely that this distribution has occurred by chance because Srupson, Gunson and Smithres (1962) found an excess of the phenotype $\mathrm{Hp} 2-2$ among their diabetic pationts.

In the Gm system, the excess of $\mathrm{Gm}(\mathrm{a}+\mathrm{b}-\mathrm{x}+)$ and lack of Gm $(a+b-x-)$ individuals among the diabetes mellitus patients, was statistically significant. As with the $\mathrm{Hp}$ and Rh systems, this possible association with diabetes mellitus must await the collection of more data, for final evaluation.

No indication of association with diabetes mellitus was found in the Ge system or in the $\beta$-lipoprotein systems Ld, Lp and Ag. The observation of BLum- 
BERG (1964) of an association with the Ag system was hence not confirmed. Thus the occurrence of diabetes mellitus does not appear to be related to any presently known genetic type of human serum $\beta$-lipoprotein.

Some of the statistical tests in the present study resulted in $P$ values sufficiently. low to suggest the existence of associations. Because of the pitfalls of association studies (reviewed by Clarke, 1964) the present data should, however, be interpreted with caution. We can exclude errors caused by blood transfusion (CLARKE, 1964) in the patient group, as none had been transfused in the 3 months prior to obtaining the blood samples. Some of the highest $\chi^{2}$ values may have resulted from a true association, but there is a need to collect more data.

\section{References}

AIRd, I., H.H. Bentall and J.A.F. Roberts: A relationship between cancer of stomach and the ABO blood groups. Brit. med. J. 1953 I, 799-801.

ANDERSEN, J., and E. LAURTTzEN : Blood groups and diabetes mellitus. Diabetes 9, 20-24 (1960).

Berg, K. : A new serum type system in man - the $\mathrm{Lp}$ system. Acta path. microbiol. scand. 59, 369-382 (1963).

- Comparative studies on the $\mathrm{Lp}$ and Ag serum type systems. Acta path. microbiol. scand. 62, 276-286 (1964).

- A new serum type system in man - the Ld system. Vox Sang. 10, 513-527 (1965).

BLUMBERg, B.S.: Polymorphisms of the serum proteins and the development of iso-precipitins in transfused patients. Bull. N.Y. Acad. Med. 40, 377-386 (1964).

BUCKwalter, J.A., and G.V. Tweed: The Rhesus and MN blood groups and disease. J. amer. med. Ass. 179, $479-485(1962)$.

ClakkE, C.A.: Genetics for the clinician; 2nd Ed., pp. 107-111. Philadelphia: F.A. Davis Company 1964.
Fleischer, E.A., and J. Lundevall : Inheritance of serum groups. Proc. VIth Congr. europ. Soc. Haemat., Copenhagen 1957, pp. 906-908. Basel/New York: Karger 1958.

HARBOE, M., and J. Londevali: The application of the Gm system in paternity cases. Vox Sang. 6, 257-273 (1961).

Hartmans, O., O.J. Bremdemome and C. Brendemoen: Rh (CcDE) genotypes of 1000 Norwegians. Acta path. microbiol. scand. 29, $451-453$ (1951).

-, and J. LUNDEVALL: Blood group distribution in Norway with special regard to the $\mathrm{MN}$ and $\mathrm{O} \mathrm{A}_{1} \mathrm{~A}_{2} \mathrm{~B}$ system. Oslo: Jacob Dybwad 1944.

Heistö, H.: The frequency of the Kell antigen in the population of Oslo. Acta path. microbiol. scand. 33, $433-434$ (1953).

MACAFEe, A.L.: Blood groups and diabetes mellitus. J. clin. Path. 17, 39-41 (1964).

MoConnele, R.B., D.A. Pyke and J.A.F. Roberts: Blood groups in diabetes mellitus. Brit. med. J. 1956 I $772-776$.

RACE, R.R., and R. SANGER: Blood groups in man; 4th Ed. Philadelphia: F.A. Davis Company 1962.

ReINskod, T.: Distribution of the Ge types in Norway. Acta genet., Basel 15, 33-44 (1965).

StMpson, N.E., H.H. Gunson and O. Smtrites: Frequencies of blood groups, serum haptoglobins and levels of slow alpha ${ }_{2}$-globulin in diabetics and their relatives. Diabetes 11, 329-333 (1962).

Dr. K. Berg

The Rockefeller University

New York 10021

Now York (U.S.A.)

Dr. S. Aarseth

Department of Internal Medicine

Diakonhjemmets sykehus

Oslo (Norway)

Drs. J. Lundevalu and T. Reinsmou

Institute of Forensic Medicine

University of Oslo, Rikshospitalet

Oslo (Norway) 